\title{
Studies on N-metabolism in different gastrointestinal sections of sheep using the digesta exchange technique. 1. Model and experimental conditions *
}

\author{
A. Sandek ${ }^{1,5}$, K. Krawielitzki ${ }^{2}$, J. Kowalczyk ${ }^{3}$, F. Kreienbring ${ }^{2}$, \\ M. Gabel ${ }^{1}$, T. Żebrowska ${ }^{3}$ and J. Voigt ${ }^{4}$ \\ 'Institute for Ecologically-Compatible Animal Husbandry, University of Rostock \\ Justus-von-Liebig-Weg 8, 18059 Rostock, Germany \\ ${ }^{2}$ Institute for Applied Agroecology, Rostock, Germany \\ ${ }^{3}$ Kielanowski Institute of Animal Physiology and Nutrition, \\ Polish Academy of Sciences \\ 05-110 Jablonna, Poland \\ ${ }^{4}$ Research Institute for the Biology of Farm Animals, \\ Department of Nutritional Physiology „Oskar Kellner“ \\ Wilhelm-Stahl-Allee 2, 18196 Dummerstorf, Germany
}

(Received 27 June 2001; accepted 7 August 2001)

\section{ABSTRACT}

The aim of the study was to measure the secretion, passage and reabsorption of $\mathrm{N}$ in the gastrointestinal tract of sheep using the method of digesta exchange between ${ }^{15} \mathrm{~N}$ labelled and unlabelled sheep. This requires information on $\mathrm{N}$ passage in different parts of the intestinal tract. Six experiments were carried out, each with three male sheep of $20-25 \mathrm{~kg}$ body weight, fitted with a cannula into the rumen, with re-entrant cannulas in the proximal duodenum and distal ileum and with a jugular vein catheter for blood sampling. The animals were fed in $4 \mathrm{~h}$ intervals with a hay and concentrate diet, where Group 1 (Experiments 1 to 3 ) received a ration of low crude fibre $(15 \% \mathrm{CF})$ with a hay:concentrate ratio of 38:62, and Group 2 (Experiments 4), a ration of high crude fibre $(25 \% \mathrm{CF})$ with a hay:concentrate ratio of $64: 36$. The diets were isonitogenous $(\sim 16 \% \mathrm{CP})$. In each experiment one of the three sheep (animal No. 1) was infused intraruminally with ${ }^{15} \mathrm{~N}$ urea $(1 \mathrm{~g} / \mathrm{d}$,

\footnotetext{
* Supported by the Deutsche Forschungsgemeinschaft (DFG) and Schaumannstiftung and by the State Committee for Scientific Research

$s$ Corresponding author
} 
95 atom $\%{ }^{15} \mathrm{~N}$ ), the others, No. 2 and No. 3, were infused with unlabelled urea. After the ${ }^{15} \mathrm{~N}$ level of the metabolic pool of animal No.1 reached a steady state, passage of digesta, dry matter, total N, and

${ }^{15} \mathrm{~N}$ at the duodenum and the ileum and $\mathrm{N}$ and ${ }^{15} \mathrm{~N}$ excretion in faeces and urine were estimated. For the determination of $\mathrm{N}$ secretion and reabsorption, on day 7 and 8 of the experiment the duodenal and the ileal digesta were exchanged between the labelled animal (No. 1) and the unlabelled ones (No. 2 and 3). The digesta flow was measured directly during $48 \mathrm{~h}$ and $3 \%$ aliquots of the duodenal and ileal digesta were taken for analysis of $\mathrm{N}$ and ${ }^{15} \mathrm{~N}$ content. Mean $\mathrm{N}$ balance ( $\pm \mathrm{SD}$ ) for Group 1 (low $\mathrm{CF}$ content) was $5.80 \pm 1.66 \mathrm{~g} \mathrm{~N} / \mathrm{d}$ and for Group 2 (high CF content) $-1.11 \pm 1.12 \mathrm{~g} \mathrm{~N} / \mathrm{d}$. Total $\mathrm{N}$ excretions for Group 1 were significantly smaller than for Group 2 (urine: 43 vs $71 \%$ of $N$ intake; facces: 27 vs $38 \%$ of $\mathrm{N}$ intake). Mean daily $\mathrm{N}$ excretions in faeces were 5.21 and $4.86 \mathrm{~g}$ for Groups 1 and 2 , respectively and were positively correlated $\left(R^{2}=0.912\right)$ with $C F$ intake. For determination of $N$ flow rates out of the stomachs into the duodenum it was necessary to correct the flow rates measured at the duodenal fistula by the secretion rates of pancreas and bile. These secretion rates, estimated in a separate experiment, were 2.20 and $0.93 \mathrm{~g} \mathrm{~N} / \mathrm{d}$ for Groups 1 and 2 , respectively. Corresponding $\mathrm{N}$ flows out of the stomachs into the duodenum were 12.2 and $11.6 \mathrm{~g} / \mathrm{d}$ and were higher than the $\mathrm{N}$ intake for the group with higher $\mathrm{CF}$ content. Ileal $\mathrm{N}$ flow was positively correlated to $\mathrm{CF}$ intake $\left(\mathrm{R}^{2}=0.819\right)$. For Groups I and 2, $\mathrm{N}$ disappearance rates were 57.9 and $45.6 \%$, respectively for the small intestine, 26.5 and $30.1 \%$ for the large intestine, and 76.5 and $62.2 \%$ for the whole digestive tract.

KEY WORDS: sheep, passage rate, $\mathrm{N}$ flow rates, disappearance rates, ${ }^{15} \mathrm{~N}$, crude fibre

\section{INTRODUCTION}

During digestion in ruminants, considerable amounts of N in the form of NPN, enzymatic proteins, mucoproteins and scrubbed epithelial cells are secreted and, for the most part, reabsorbed. The secretion of endogenous proteins into the stomach and gut may result in a decreased efficiency of conversion of absorbed amino acids into tissue proteins (Makking, 1993).

Therefore it is of great interest to quantify the amount of secretion and reabsorption of $\mathrm{N}$ and to estimate the factors influencing the production and reabsorption of endogenous N. Knowledge about this topic is still scanty. Recently, new methods such as the loop technique (Żebrowska and Kowalczyk, 1991), multiple fistulation and ${ }^{15} \mathrm{~N}$ isotope technique (Siddons et al., 1985; Van Bruchem et al., 1997) were used to study $\mathrm{N}$ digestion processes in different sections of the digestive tract. The method of digesta exchange between ${ }^{15} \mathrm{~N}$ labelled and unlabelled animals cnables the simultaneous estimation of flow, secretion and reabsorption of endogenous $\mathrm{N}$ in different sections of the digestive tract. This method was used on pigs up to now (Żebrowska et al., 1992; Krawielitzki et al., 1996). Because of the differences in the gastrointestinal tract of monogastric animals and ruminants, the method had to be modified. It must be taken into account that the $\mathrm{N}$ entry into the gut is of microbial, dictary and endogenous origin and that $\mathrm{N}$ recycling exists between the rumen and liver. 
The aim of this study was to quantify the flow, the secretion and the reabsorption rates of $\mathrm{N}$ in different sections of the gastro-intestinal tract influenced by dietary fibre. In this paper, the model, experimental conditions and preliminary results are presented.

\section{MATERIAL AND METHODS}

\section{Modelling}

The model used one ${ }^{15} \mathrm{~N}$ labelled and two unlabelled sheep equipped with cannula into the rumen and re-entrant cannulas into the duodenum and terminal ileum. The digesta exchange between these 3 animals (Figure 1) lead to intestinal sections in which ${ }^{15} \mathrm{~N}$ enrichment increases in the labelled animal or decreases in unlabelled animals. The appearance and disappearance rates of ${ }^{15} \mathrm{~N}$ allow calculation of endogenous $\mathrm{N}$ flow and secretion and reabsorption to be followed. Thereby it is assumed that the ${ }^{15} \mathrm{~N}$ excess of endogenous $\mathrm{N}$ and of the TCA soluble fraction of the plasma is identical. Information about bile and pancreas secretions is needed because the duodenal cannulas are positioned after the ductus choledochus/ ductus pancreaticus and was obtained in a separate experiment.

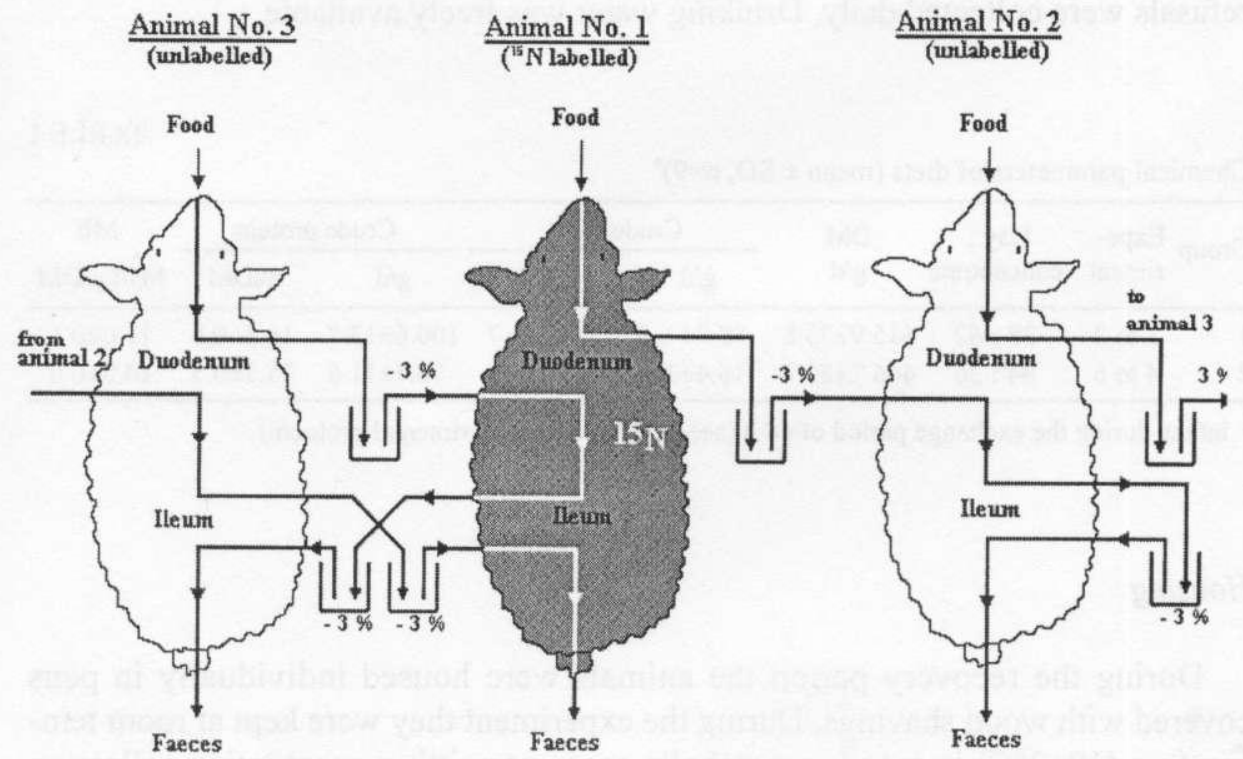

Figure 1. Schematic description of digesta exchange between labelled and unlabelled sheep 


\section{Exchange experiments}

\section{Animals}

Six experiments each with 3 sheep were carried out. Animals were 5-monthold Polish Merino whether sheep of $20-25 \mathrm{~kg}$ body weight, each fitted with a cannula into the rumen and re-entrant cannulas into the duodenum (distal to the ductus choledochus and ductus pancreaticus, 20-40 cm behind the pylorus,) and terminal ileum (about $25 \mathrm{~cm}$ before the ileocaecal junction). The animals were fitted with a polyurethane catheter $(\varnothing 1.8 \mathrm{~mm})$ into the jugular vein for blood sampling.

During the whole experiment the animals were under veterinary control.

\section{Feeding}

In Group 1 (Experiments 1,2 and 3) the animals were offered a diet with a hay to concentrate ratio of $38: 62$; in Group 2 (Experiments 4, 5 and 6) of $64: 36$ (DM basis). The concentrate consisted of (\%): barley, 82.2 ; soyabean meal, 15.8; and mineral mixture, 2 . The diets were isonitrogenous $(\sim 16 \%$ crude protein, $\mathrm{CP})$ but, for estimation of the possible influence of fibre, differed in crude fibre (CF) content (Group 1-15\%; Group 2 - 25\% of DM). Details of the diets are given in Table 1 . The daily rations were given in 6 equal portions at $4 \mathrm{~h}$ intervals; feed refusals were collected daily. Drinking water was freely available.

TABLE 1

Chemical parameters of diets (mean $\pm \mathrm{SD}, \mathrm{n}=9)^{*}$

\begin{tabular}{|c|c|c|c|c|c|c|c|c|}
\hline \multirow{2}{*}{ Group } & \multirow{2}{*}{$\begin{array}{l}\text { Expe- } \\
\text { riment }\end{array}$} & \multirow{2}{*}{$\begin{array}{c}\text { Hay: } \\
\text { concentrate }\end{array}$} & \multirow{2}{*}{$\begin{array}{l}\mathrm{DM} \\
\mathrm{g} / \mathrm{d}\end{array}$} & \multicolumn{2}{|c|}{ Crude fibre } & \multicolumn{2}{|c|}{ Crude protein } & \multirow{2}{*}{$\begin{array}{c}\mathrm{ME} \\
\mathrm{MJ} / \mathrm{kg} \mathrm{DM}\end{array}$} \\
\hline & & & & $g / d$ & $\% \mathrm{DM}$ & $g / d$ & $\% \mathrm{DM}$ & \\
\hline 1 & 1 to 2 & $38: 62$ & $615.9 \pm 73.8$ & $89.7+6.3$ & $14.7 \pm 1.7$ & $100.6 \pm 13.7$ & $16.3 \pm 0.6$ & $11.0 \pm 0.1$ \\
\hline 2 & 4 to 6 & $64: 36$ & $466.7 \pm 89.9$ & $116.4 \pm 31.3$ & $24.9 \pm 1.9$ & $73.1 \pm 11.6$ & $15.7 \pm 0.5$ & $10.0 \pm 0.0$ \\
\hline
\end{tabular}

- intake during the exchange period of $48 \mathrm{~h}$ (see detaits of the experimental protocol)

\section{Housing}

During the recovery period the animals were housed individually in pens covered with wood shavings. During the experiment they were kept at room temperature $\left(18 \pm 2^{\circ} \mathrm{C}\right)$ in wooden metabolic cages permitting quantitative collection of faeces and urine and sampling of ruminal, duodenal, and ileal digesta. 


\section{Experimental protocol}

The experiments were started four weeks after surgery. Each expcriment was divided into 3 periods: labelling (day 1 to day 6), digesta exchange (day 7 to day 8 ), and clearance (day 9 to 10 ). During the labelling and the exchange periods, animal No. 1 in each experiment was continuously infused intraruminally with ${ }^{15} \mathrm{~N}$ labelled urea $\left(1 \mathrm{~g}{ }^{15} \mathrm{~N}\right.$ urea/d; 95 atom $\left.\%{ }^{15} \mathrm{~N}\right)$. Animals No. 2 and 3 were simultaneously infused intraruminally with the same amount of unlabelled urea.

During the two days of the digesta exchange period the duodenal and the ileal digesta were collected continuously and weighted. Three percent aliquots from $4 \mathrm{~h}$ intervals were pooled and stored at $-20^{\circ} \mathrm{C}$ until analysis for $\mathrm{N}$ and ${ }^{15} \mathrm{~N}$ content. During collection the digesta was kept on ice and after sampling and warming to $38^{\circ} \mathrm{C}$ reinfused according to the digesta exchange scheme given in Figure 1.

Faeces and urine were sampled during all 3 periods. Faeces were weighed daily and then preserved with a few drops of chloroform. Urine was collected using a device for quantitative collection according to Kowalczyk et al. (1996). Daily collections were made into vessels containing $100 \mathrm{ml} 6 \mathrm{~N} \mathrm{HCl}$ to prevent $\mathrm{N}$ loss as ammonia. However, for animal No. 1 on day 1 (start of the labelling period) and on day 9 (first day of the clearance period), shorter intervals of 4 to $12 \mathrm{~h}$ were chosen. All samples were frozen at $-20^{\circ} \mathrm{C}$ until analysis.

Additionally samples of about $50 \mathrm{ml}$ rumen fluid and of $5 \mathrm{ml}$ blood were taken before the morning feeding at 8.00 during the whole experimental period. From rumen fluid, bacterial matter was separated by fractional centrifugation according to Beever et al. (1994). $\mathrm{N}$ and ${ }^{15} \mathrm{~N}$ were estimated in the lyophilized material.

\section{Chemical analysis and calculation}

Analysis for $\mathrm{N}$ was done by the Kjeldahl method and for ${ }^{15} \mathrm{~N} /{ }^{14} \mathrm{~N}$ ratio after chemical preparation according to Voigt et al. (1980) and Faust et al. (1981) by means of isotope mass spectrometry using a Delta S (Finnigan MAT, Bremen, Germany) instrument. Crude protein was calculated as $\mathrm{N} \times 6.25$. DM and $\mathrm{CF}$ was determined according to procedure described by Naumann and Bassler (1983).

The estimation of flow and excretion rates was carried out during the 2-dayexchange period. Because this time was too short for estimation of $\mathrm{N}$ excretion in faeces in relation to $\mathrm{N}$ intake, excretion rates during the 6-day-labelling period (balance period) were used for calculating faecal $\mathrm{N}$ loss during the exchange period.

\section{Statistical analysis}

The results were analysed statistically using SPSS, Version 10.0. Differences were tested by means of Student's t-test (two-way) with $\mathrm{P}<0.05$ as the level of significance. All results were given as a mean with standard deviation (SD). 


\section{Experiment for measurement of bile and pancreas secretions}

The measurements were carried out on 4 male sheep (Polish Merino, 26 to $29 \mathrm{~kg} \mathrm{BW}$ ) fed diets similar to the diets in the exchange experiment (Table 2). The animals were equipped with a rumen cannula, catheter at $\mathrm{d} u c t u s$ choledochus/ductus pancreaticus and a re-entrant cannula at the duodenum. The surgical technique was described by Phaneuf (1961). The housing of animals, experimental protocol and chemical analysis were like those in the exchange experiments. However, ${ }^{15} \mathrm{~N}$ urea was infused into the jugular vein. Furthermore, no exchange of digesta between animals was carried out. Five percent of secretions were pooled each $8 \mathrm{~h}$. The duodenal digesta was reinfused together with remaining secretions from bile and pancreas into the distal cannula at the duodenum.

TABLE 2

Diets in experiments on sheep with catheters in bile-pancreatic duct $(n=2)$

\begin{tabular}{|c|c|c|c|c|c|c|c|}
\hline \multirow{2}{*}{ Sheep } & \multirow{2}{*}{$\begin{array}{c}\text { Hay: } \\
\text { concentrate }\end{array}$} & \multirow{2}{*}{$\begin{array}{l}\text { DM } \\
g / d\end{array}$} & \multicolumn{2}{|c|}{ Crude fibre } & \multicolumn{2}{|c|}{ Crude protein } & \multirow{2}{*}{$\begin{array}{c}\mathrm{ME} \\
\mathrm{MJ} / \mathrm{kg} \mathrm{DM}\end{array}$} \\
\hline & & & $\mathrm{g} / \mathrm{d}$ & $\% \mathrm{DM}$ & $\mathrm{g} / \mathrm{d}$ & $\% \mathrm{DM}$ & \\
\hline 1,2 & $35: 65$ & 669 & 114 & 17.1 & 114 & 17.0 & 10.6 \\
\hline 3,4 & $73: 27$ & 556 & 169 & 30.3 & 73 & 13.1 & 8.3 \\
\hline
\end{tabular}

\section{RESULTS}

Experiment 3 could be only used for measurement of digesta flow rate, urinary and faecal $\mathrm{N}$ excretion because the duodenal re-entrant cannulas were placed proximally to the bile duct in one animal.

\section{$N$-balance}

In all experiments, the $\mathrm{N}$-balance was estimated during a labelling period of 6-7 days. In Table 3 the N-balance for both feeding groups is shown. The mean $\mathrm{N}$-balance for Group 1 was $5.8 \pm 1.7 \mathrm{~g} / \mathrm{d}$ (about $30 \%$ of $\mathrm{N}$-intake), that for Group 2, nearly zero $(-1.1 \pm 1.1 \mathrm{~g} / \mathrm{d})(\mathrm{P}<0.05)$.

${ }^{15} \mathrm{~N}$ excess in urine, blood and microbes

The slope of ${ }^{15} \mathrm{~N}$-level was determined in urine, in TCA-soluble fraction of plasma $\mathrm{N}$ and in isolated rumen microbes during the whole experiment to check the steady state for the ${ }^{15} \mathrm{~N}$-level of the metabolic pool in the labelled sheep. The 
$\mathrm{N}$ balance during the labelling period $(6 \mathrm{~d} ;$ mean $\pm \mathrm{SD})$

\begin{tabular}{lcc}
\hline & Group $1(\mathrm{n}=9)$ & Group $2(\mathrm{n}=9)$ \\
\hline Crude fibre - intake & $110.6 \pm 14.7 \mathrm{~g} / \mathrm{d}$ & $144.2 \pm 23.2 \mathrm{~g} / \mathrm{d}$ \\
$\mathrm{DM}-$ intake & $754 \pm 80 \mathrm{~g} / \mathrm{d}$ & $536 \pm 63 \mathrm{~g} / \mathrm{d}$ \\
$\mathrm{N}$ intake, g/d & $19.18^{\mathrm{a}} \pm 1.96$ & $12.97^{\mathrm{b}} \pm 1.33$ \\
Feed-N, g/d & $18.1^{\mathrm{a}} \pm 2.00$ & $12.51^{\mathrm{b}} \pm 1.33$ \\
Infused-N, g/d & $0.46 \pm 0.01$ & $0.46 \pm 0.01$ \\
& & \\
$\mathrm{~N}$ excretion & & \\
urine $\mathrm{N}, \mathrm{g} / \mathrm{d}$ & $8.17 \pm 1.33$ & $9.23 \pm 0.47$ \\
$\%$ of intake & $42.6 \pm 6.9$ & $71.2 \pm 3.6$ \\
& & $4.86 \pm 0.55$ \\
facces, g/d & $5.21 \pm 0.99$ & $37.5 \pm 4.2$ \\
$\%$ of intake & $27.2 \pm 5.2$ & $-1.11^{\mathrm{b}} \pm 1.12$ \\
$\mathrm{~N}$ balance, g/d & $5.80^{\mathrm{a}} \pm 1.66$ & $-8.6 \pm 9.9$ \\
$\%$ of intakc & $30.2 \pm 7.6$ & \\
\hline
\end{tabular}

${ }^{\mathrm{a}, \mathrm{b}} \mathrm{P}<0.05$

course of ${ }^{15} \mathrm{~N}$-excess is shown in Figure 2. These curves show an increase of the ${ }^{15} \mathrm{~N}$ level for all three $\mathrm{N}$ fractions reaching a plateau value within 4 to 6 days. So the steady state condition for ${ }^{15} \mathrm{~N}$-level in labelled sheep was achieved before starting the exchange digesta period.

\section{Flow rates of digesta}

The passage rates through the duodenum and the ileum and the rates of excretion in faeces were estimated during the digesta exchange period. Food intake during this period was not exactly the same as during the labelling period, therefore the values for intake and for excretion in the faeces and urine differed from those for the N-balance period.

Because of the position of the duodenal cannulas, the $\mathrm{N}$ flow rates measured at the duodenal cannula included the $\mathrm{N}$ secretion of pancreas and bile. It was therefore necessary to correct the $\mathrm{N}$ flow rates for the $\mathrm{N}$ excretion from these sites. The secretion rates of the pancreas-bile juice are summarized in Table 4.

These values were adopted for the present experiments in order to calculate the outflow of original substance, dry matter and nitrogen from of the stomachs into the duodenum.

The intake and the flow rates during the exchange period of $48 \mathrm{~h}$ are given in Figures 3 to 5 . The mean digesta flow rates measured at the duodenum during the digesta exchange period of $48 \mathrm{~h}$ were $5.78 \mathrm{~kg} / \mathrm{d}$ for Group 1 and $6.76 \mathrm{~kg} / \mathrm{d}$ for 


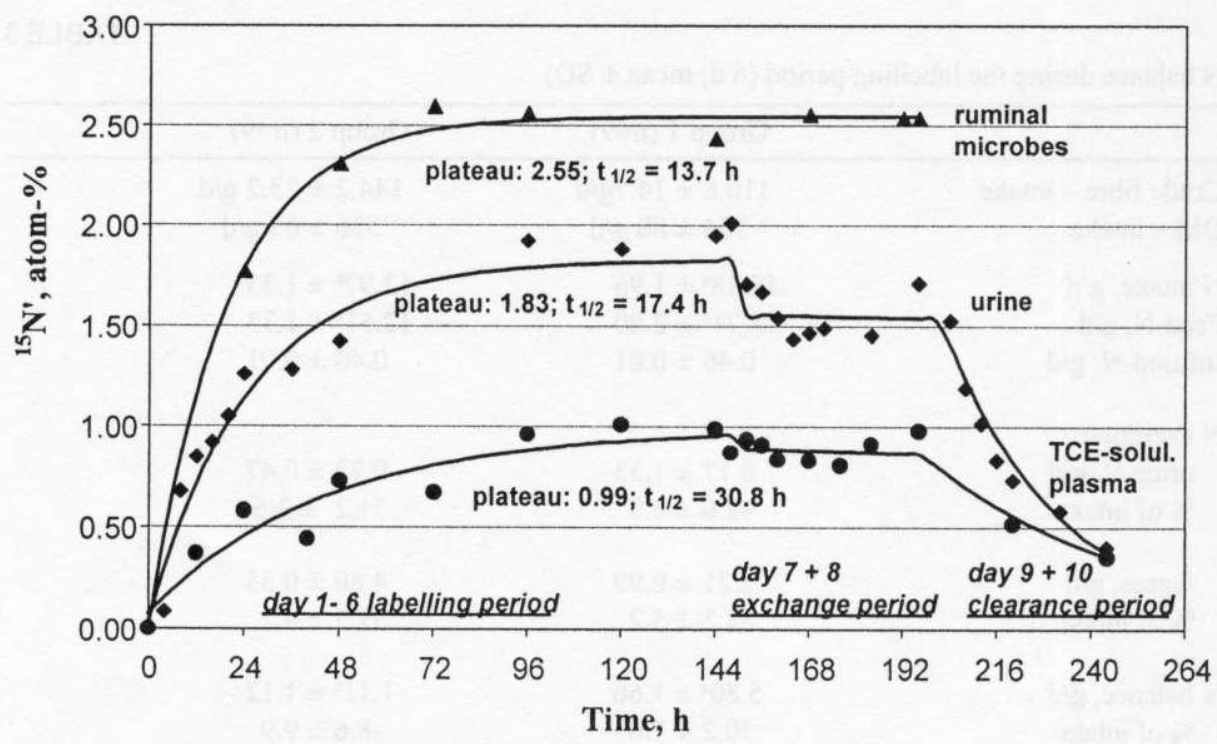

Figure 2. Course of ${ }^{15} \mathrm{~N}$ excess for urine $\mathrm{N}$, TCE soluble blood plasma $\mathrm{N}$ and protein of ruminal microbes

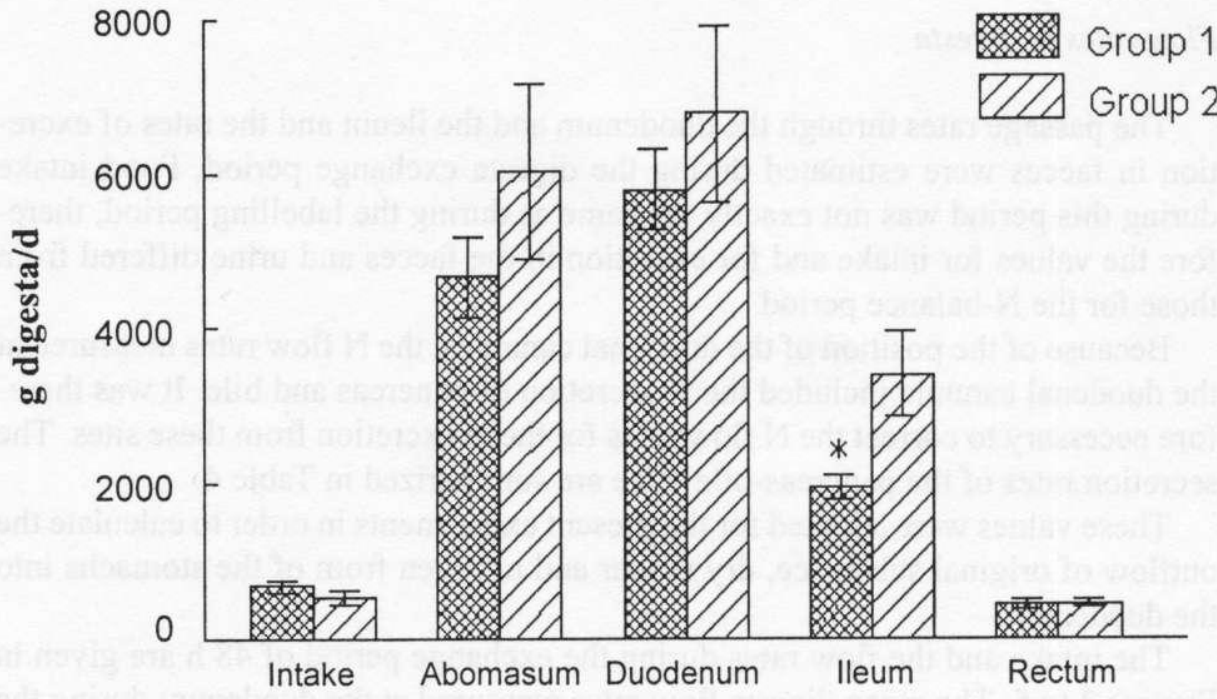

Figure 3. Feed intake and digesta flow rate $(n=9$, Mean \pm SD) 
TABLE 4

Secretion rates of bile and pancreatic juice

\begin{tabular}{lcc}
\hline Indices & Group I & Group 2 \\
\hline Measured data (n=2) & 669 & 556 \\
DM intake g/d & 17.0 & 13.1 \\
dictary CP content in DM, \% & 17.1 & 30.3 \\
dietary CF content in DM, \% & 1027 & 742 \\
secretion, g/d & 1526 & 1351 \\
g/kg DM intake & 2.32 & 1.10 \\
g N/d & 3.50 & 2.00 \\
g N/kg DM intake & & \\
& 616 & 467 \\
Calculated data for exchange studies & 946 & 623 \\
DM intake, g/d & 2.20 & 0.93 \\
secretion, g/d & & \\
g N/d & & \\
\hline
\end{tabular}

Group 2. The corresponding values at the distal ileum were 1.94 and $3.40 \mathrm{~kg} / \mathrm{d}$. The flow rate for Group 2 was significantly higher than that for Group $1(\mathrm{P}<0.05)$, even the DM intake was significantly lower. Figure 4 demonstrates the estimated flow rates of DM. Although the DM intake for both groups differed, DM passage at the duodenum was similar. The mean duodenal DM passage was $301 \mathrm{~g} / \mathrm{d}$ for Group 1 and $331 \mathrm{~g} / \mathrm{d}$ for Group 2; corresponding values for ileal digesta were 162 and $250 \mathrm{~g} / \mathrm{d}(\mathrm{P}<0.05)$ and for faeces 137 and $156 \mathrm{~g} / \mathrm{d}$. The disappearance rate of DM for Group 1 was $78 \%$ and for Group 2, 68\%. The DM disappearance rate in the small intestine (intestinal section: stomach to ileum) was $38 \%$ (Group 1) and $18 \%$ (Group 2). For the large intestine (intestinal sections: ileum to rectum) the values were 17 and $39 \%$. DM passage (y) at the ileum was positively correlated with CF intake $(x): y=1.70 x+36.1 ; R^{2}=0.70$.

\section{Nitrogen passage}

The $\mathrm{N}$ intake and the $\mathrm{N}$ flow rates during the digesta exchange period are given in Figure 5. No differences of the $\mathrm{N}$ flow were found between the groups at the various sites. For Group 1 the $\mathrm{N}$ flow rate at the duodenum was smaller than $\mathrm{N}$ intake ( 91\%), for Group 2 it was higher $(\sim 107 \%)$.

Figure 6 gives the $\mathrm{N}$ flow rates for the duodenum, ileum, and faeces, the $\mathrm{N}$ disappcarance rates for the three intestinal sections, stomachs, small intestine, and large intestine as well as the disappearance rates for the postruminal section and for the total intestine. The disappearance rate of the total intestinal tract for Group 2 was smaller than for Group 1 ( 62 vs $77 \% ; \mathrm{P}<0.05)$ 


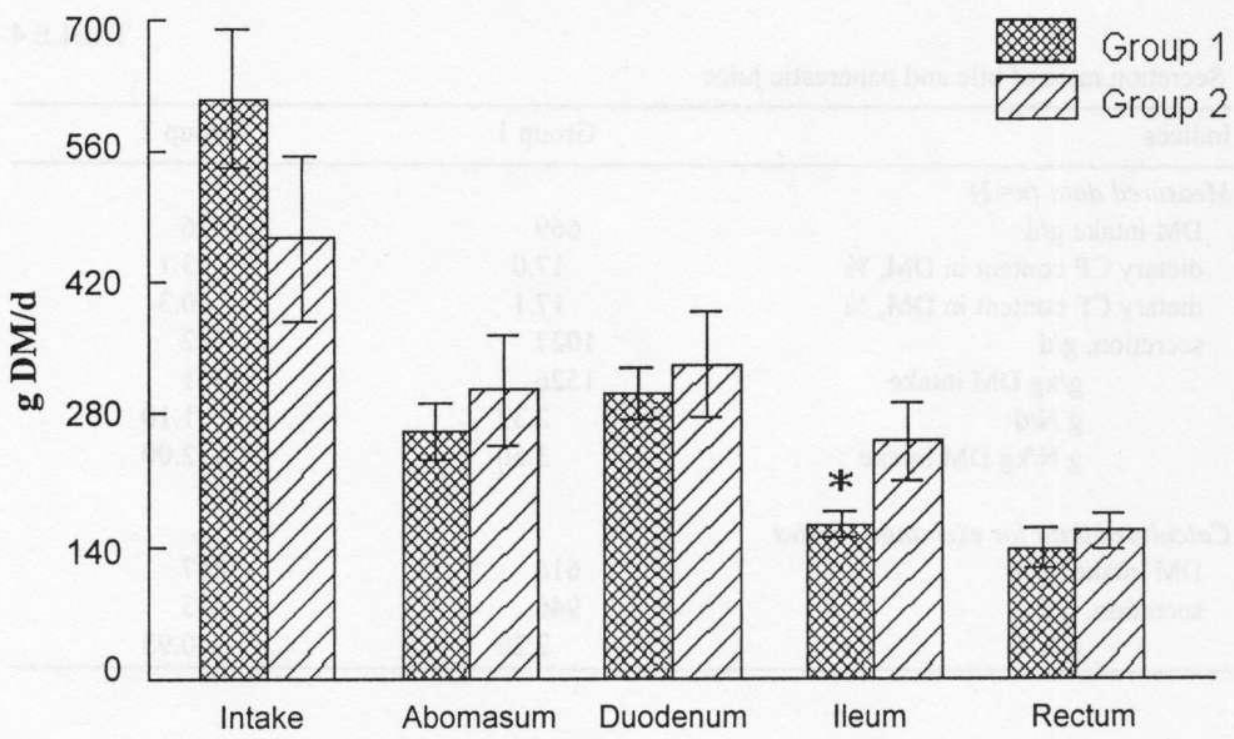

Figure 4. Intake and gastro-intestinal flow rates of dry matter $(n=9$, Mean $\pm S D)$

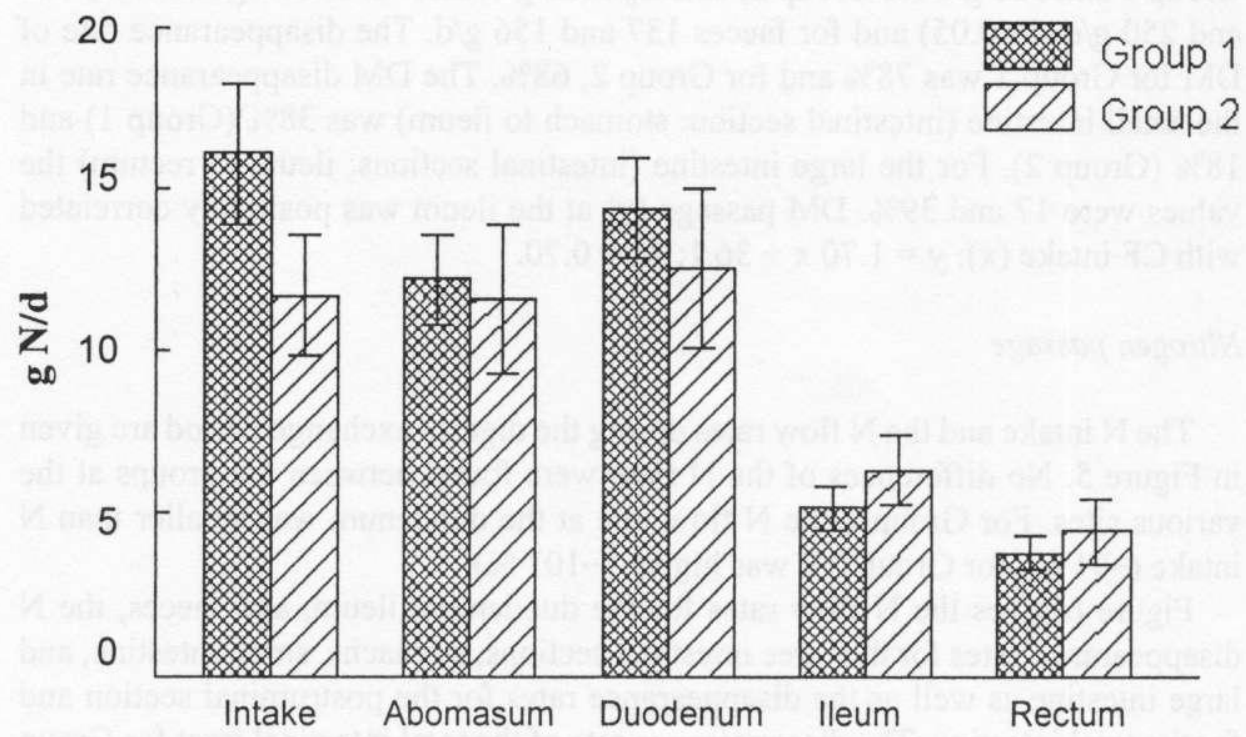

Figure 5. Intake and gastro-intestinal flow rates of nitrogen $(n=9$, Mean \pm SD) 


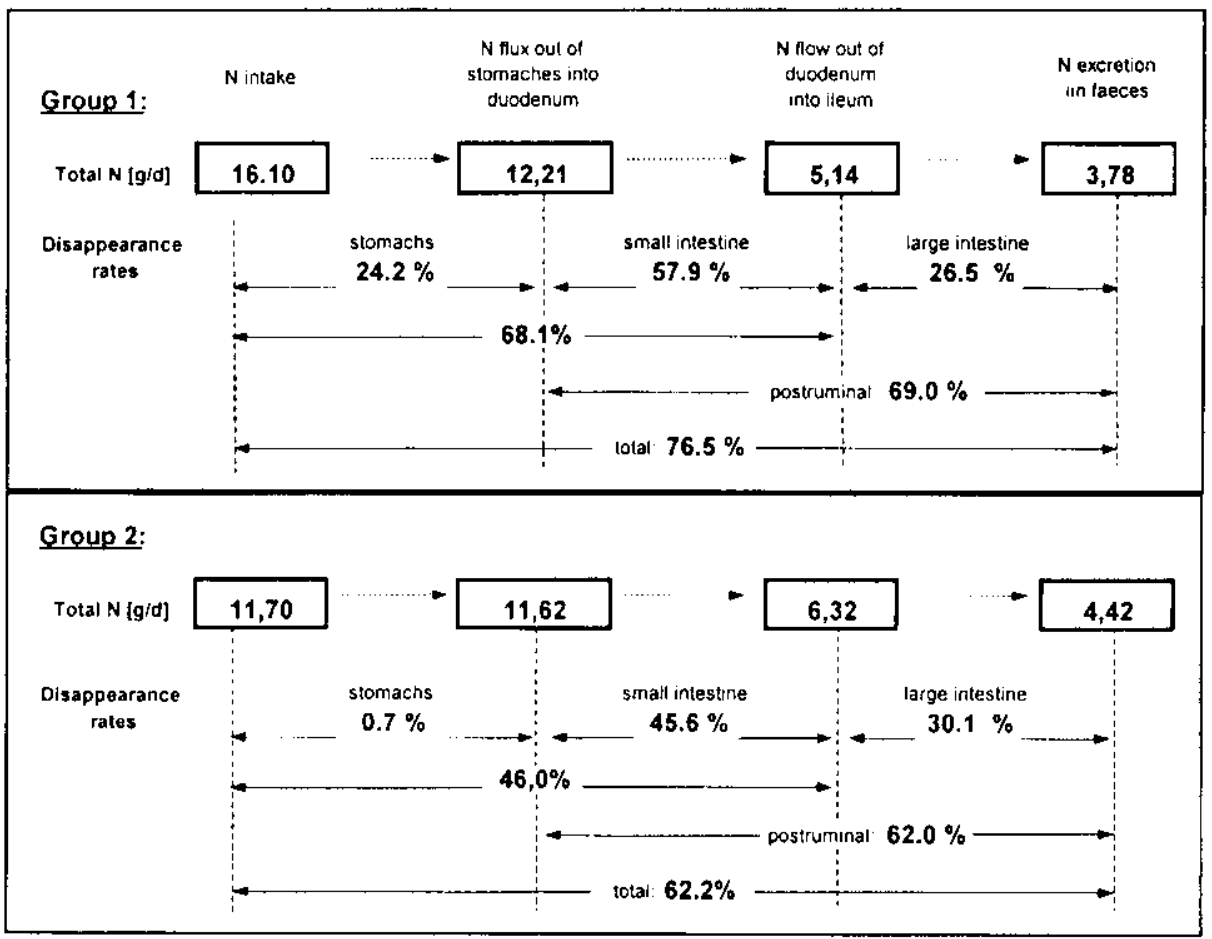

Figure 6. $N$ flux rates and disappcarance rates in different intestinal sections $(n=2$, Group 1 ; $n=3$, Group 2)

The greatest disappearance of $\mathrm{N}$ occurred within the second section, the small intestine $(58 \%$ of the $\mathrm{N}$ that entered for Group 1 and $46 \%$ for Group 2; i.e. 44 to $45 \%$ of $\mathrm{N}$ intake for both groups). During passage through the large intestine the $\mathrm{N}$ disappearance rate was also high (27 and $30 \%$ of the $\mathrm{N}$ that entered this section, equivalent to 8 and $16 \%$ of $\mathrm{N}$ intake). Because of the difference in dietary $\mathrm{CP}$ concentration, a significant difference $(P<0.05)$ was measured between both feeding groups for the first section (stomachs). For Group 1 the disappearance rate was $24 \%$ of the $\mathrm{N}$ intake, for Group 2 it was nearly zero. The $\mathrm{N}$ flux into the duodenum was approximately the same for both groups.

\section{DISCUSSION}

The measured passage of nutrients in this digesta exchange experiment corresponds with those from investigations on single animals with multiple cannulas (Siddons et al., 1985; Van Bruchem et al., 1997). Hence it follows that the method 
is suitable in principle for the measurement of passage rates along the gastrointestinal tract of the sheep. The results show further agreement with Schönhusen et al. (1999) that a high dietary CF content enhances the passage rate of digesta (Figures 3 and 4).

The $\mathrm{N}$ balance in Group 1 (smaller CF content in the ration) was higher (5.8 $\mathrm{g}$ $\mathrm{N} / \mathrm{d})$ than that for Group $2(-1.1 \mathrm{~g} \mathrm{~N} / \mathrm{d})$ which had a higher CF content in the feed. In this experiment it is not possible to attribute these differences solely to the $\mathrm{CF}$ content of the diet as there were also differences in DM intake (Table 2), which in turn resulted in differences in both protein and energy intake. The results of other authors regarding the influence of CF in pigs (Bergner et al., 1983) support this assumption. The smaller $\mathrm{N}$ balance for Group 2 seems to be caused, for the most part, by the smaller intake of $\mathrm{N}$ and energy and this effect is accentuated by the higher fibre content for Group 2.

The $\mathrm{N}$ disappearance rate was highest for the second intestinal section (small intestine), demonstrating once more that the small intestine is the main region for $\mathrm{N}$ absorption during intestinal passage.

In the third section (large intestine) there was also a relatively high $\mathrm{N}$ disappearance in both groups. Because there is no absorption of amino acids in the large intestine in pigs (Żebrowska, 1973), this resorption must occur mainly in the form of ammonia, the greatest proportion of which is excreted in the urine. A partial amount will be secreted by recycling into the rumen (Egan et al., 1986). Especially if the $\mathrm{N}$ intake of the ruminants is marginal, this endogenous $\mathrm{N}$ flow compensates for the lack of exogenous $\mathrm{N}$ from feed, thereby ensuring balanced rumen microbial activity. This is the reason why the $\mathrm{N}$ disappearance rate in the first section of the intestinal tract (mouth - duodenum) showed such a large difference between groups: $24.0 \%$ for Group $1(\mathrm{~N}$ intake $=16.1 \mathrm{~g} / \mathrm{d})$, and about 0 for Group 2 $(\mathrm{N}$ intake $=11.7 \mathrm{~g} / \mathrm{d})$.

\section{REFERENCES}

Beever D.E., Harrison D.G., Thomson D.J., Cammel S.B., Osbourn D.F., 1974. A method for the estimation of dietary and microbial protein in duodenal digesta of ruminants. Brit. J. Nutr. 32, $99-112$

Bergner H., Betzin B., Simon O., 1983. Einfluß ciner Zulage von teilhydrolysiertem Strohmehl zu einer Fischmehl- oder Ackerbohnendiät auf die N-Bilanz und die Aminosäurenausschcidung über den Kot bei Schweinen. Arch. Tierernähr. 33, 815-825

Egan A.R., Bod'a K., Várady J., 1986. Regulation of nitrogen metabolism and recycling. In: L.P. Milligan, W.L. Grovum, A. Dobson (Editors). Control of Digestion and Metabolism in Ruminants. Prentice-Hall, Englewood Cliffs, NY, pp. 386-402

Faust H., Bornhak H., Hirschberg K., Jung K., Junghans P., Krumbiegel P., Reinhardt R., 1981. Klinisch-chemische und isotopenanalytische Methoden zur Untersuchung des Stickstoff- 
stoffwechsels mit ${ }^{15} \mathrm{~N}$ beim Menschen. ZFI-Mitteilungen. Berichte des Zentralinstitutes für Isotopen- und Strahlenforschung, Leipzig 36, $210 \mathrm{~S}$

Kowalczyk J., Skiba B., Buczkowski Z., Kowalik B., 1996. A device for quantitative urine collection from male sheep in balance trials. J. Anim. Feed Sci. 5, 297-301

Krawielitzki K., Żcbrowska T., Kreicnbring F., Schadereit R., Kowalczyk J., 1996. Absorption and secretion of exogenous and endogenous $\mathrm{N}$ along the digestive tract and kinetic parameters of protein metabolism in growing pigs. 1. Estimation by digesta exchange between ${ }^{15} \mathrm{~N}$-labelled and unlabelled pigs. J. Anim. Physiol. Anim. Nutr. 76, 45-56

Makking C.A., 1993. Of piglets, dietary proteins and pancreatic proteases. PhD Thesis, Wageningen Agricultural University, Wageningen (The Netherlands)

Naumann C., Bassier R, 1993. Methodenbuch, Band III. Die chemische Untersuchung von Futtermitteln. 3. Erg. Verlag J. Neumann-Neudamm, Melsungen (Germany)

Ørskov E.R., MacLeod N.A., Kyle D.J., 1986. Flow of endogenous N from the rumen and abomasum in cattle and sheep given protein-free nutrients by intragastric infusion. Brit. J. Nutr. 56, 241-248

Phaneuf L.P., 1961. Chronic duodenal and pancreatic fistulas in the sheep. J. Cornell Vet. 51, 47 56

Schönhusen U., Voigt J., Lammers-Wienhoven S.C.W., Bruchem van J., 1999. Passage of ribonucleic acid along the intestine of sheep. Arch. Anim. Nutr. 52, 335-349

Siddons R.C., Nolan J.V., Beever D.E., MacRae J.C., 1985. Nitrogen digestion and metabolism in sheep consurning diets containing contrasting forms and levels of N. Brit. J. Nutr. 54, 175-187

Van Bruchem J., Bangma G.A., Lammers-Wienhoven S.C.W., van Adrichem P.M.W., 1985b. Digestion of non-microbial protein and amino acids in the small intestine of sheep as affected by peptic proteolysis in the abomasum. Z. Tierphysiol. Tieremähr. Futtermittelk. 54, 113-121

Van Bruchem, J., Voigt J., Lammers-Wienhoven S.C.W., Schönhusen U., Ketclaars J., Tamminga S., 1997. Secretion and reabsorption of endogenous protein along the small intestine of sheep: estimates derived from ${ }^{15} \mathrm{~N}$-dilution of plasma non-protein N. Brit. J. Nutr. 77, 273-286

Voigt J., Krawielitzki R., Piatkowski B., 1980. Untersuchungen zur Wirkung von Phosphorsäurephenylesterdiamid als Inhibitor der Pansenurease bei der Milchkul. 2. Der Umsatz von ${ }^{15} \mathrm{~N}$-Harnstoff. Arch. Anim. Nutr. 30, 825-834

Żebrowska T., 1973. Digestion and absorption of nitrogen compounds in the large intestine of pigs. Rocz. Nauk. rol. B-95 (3), 85-90

Żebrowska T., Kowalczyk J., 1991. Nitrogen secretion into isolated loops of the small intestine in conscious sheep. J. Anim. Physiol. Anim. Nutr. 65, 133-139 